\title{
Accounting
}

\section{A compendium of globalization trends in world trade: Justification of a two-tire model of business processes}

\author{
Larysa Vasyurenko ${ }^{a^{*}}$, Ihor Kuksa ${ }^{b}$, Valerii Danylenko ${ }^{c}$ and Wang Jing ${ }^{d}$
}

\author{
${ }^{a}$ Dean of the Faculty of Economy, Luhansk National Agrarian University. Street. Slobozhanska, 68. 92703. Starobilsk, Ukraine \\ ${ }^{b}$ Prof. Dr. Sc. (Ekon). Luhansk National Agrarian University. Street. Slobozhanska, 68. 92703. Starobilsk, Ukraine \\ 'Senior Lecturer at the Department of Agrologistics and Supply Chain Management, PhD of Econ. Petro Vasylenko Kharkiv National \\ Technical University of Agriculture. Alchevskih str. 44. 61002. Kharkiv., Ukraine \\ ${ }^{d}$ Lecturer of the Economic Faculty, Shaanxi Vocational Technical College. Fanchuan Rd, Chang'an, Xi'an, Shaanxi, China

\begin{tabular}{l}
\hline C H R O N I C L E \\
\hline Article history: \\
Received March 62020 \\
Received in revised format March \\
302020 \\
Accepted April 142020 \\
Available online \\
April 14 2020 \\
\hline Keywords: \\
Management \\
Business process \\
Supply chain \\
Trade \\
Import \\
Export \\
Logistics
\end{tabular}

\begin{abstract}
Trading is the most sensitive sector of the economy, directly and indirectly responding to innovative challenges. High competition, political risks and planetary scales have made it susceptible to any globalization fluctuations. Effective management is seen as the most important opportunity to gain competitive advantage. This explains the increased interest in the system of indicators of management system evaluation in the business processes in the supply chains. The aim of this paper is to develop and substantiate analytical approaches to the study of the status of transnational trade economic relationships with the identification of significant impact indicators and vulnerability indicators. The globalization aspect of the existing trend of world trade (export-import) among differentiated groups of countries is justified, distinguishing the forecast component. A two-tier model of business process "reliability management" has been constructed, taking into account the results of linear regression models based on the profiles of Australia and New Zealand.
\end{abstract}

\section{Introduction}

(C) 2020 by the authors; licensee Growing Science, Canada

Today, the global business environment compels enterprises to consider restructuring the world in their competitive strategy analysis where firms ignore external factors such as economic trends, competitive positions or technology advancement in other countries (Mor et al., 2015). The functioning of supply chains as business processes in the world market is highly dependent on macroeconomic and political factors, as well as the peculiarities of technological and logistical processes, which negatively affects their operational efficiency and rhythmic flow. Formed risk management practices are usually limited by insurance, as well as capacity building and maintaining high levels of inventory. Improving the reliability of the logistics system as a whole, as well as its individual elements, along with minimizing logistics costs, is one of the ways to increase the efficiency of the logistics system in the world economy (Bochkarev \& Zaitsev, 2010).

\footnotetext{
* Corresponding author. Tel. +380956443821

E-mail address: vasyurenkolarysa@gmail.com (L. Vasyurenko)
} 
The increase in the number of publications dealing with the problems of reliability, stability and security of supply chains on a global scale is an evidence of the exceptional relevance of this problem. For example, in their research, Saha and Chakrabarti (2018) present a two-echelon supply chain model for deteriorating items, consisting of a single manufacturer and a single retailer, where the customer's demand to the retailer depends on advertisement and the displayed stock level of the retailer. According to Allen et al. (2019) "from the adoption of the shipping container to coordinated trade liberalization, reductions in trade costs have propelled modern globalization and we analyze the application of blockchain to reduce the trade costs of producing and coordinating trusted information along supply chains". Additionally, researchers in the world analyze the impact of Green Supply Chain practices on the operational performance of each company. Scientists all over the world analyze and identify in their works the emerging issues of supply chain management in specific companies, laying out the solution to the intra-company subjective components (Casey \& Wong, 2017; Tiwari et al., 2018; Sabegh et al., 2016 ). We consider it necessary for contemporary realities of world trends and challenges in the economy, specifically in trade, to put a globalization emphasis in the study of the essence of supply chains by enlarging the studied concept, growing from a micro to a macroeconomic essence: as a business process, the goal of which is the efficiency of economic activity, accordingly, maximization of profit of an economic entity, increase in gross added value of the industry, type of economic activity, growth of gross domestic product of the state. Visualization of the described scientific thought is presented in Fig. 1.

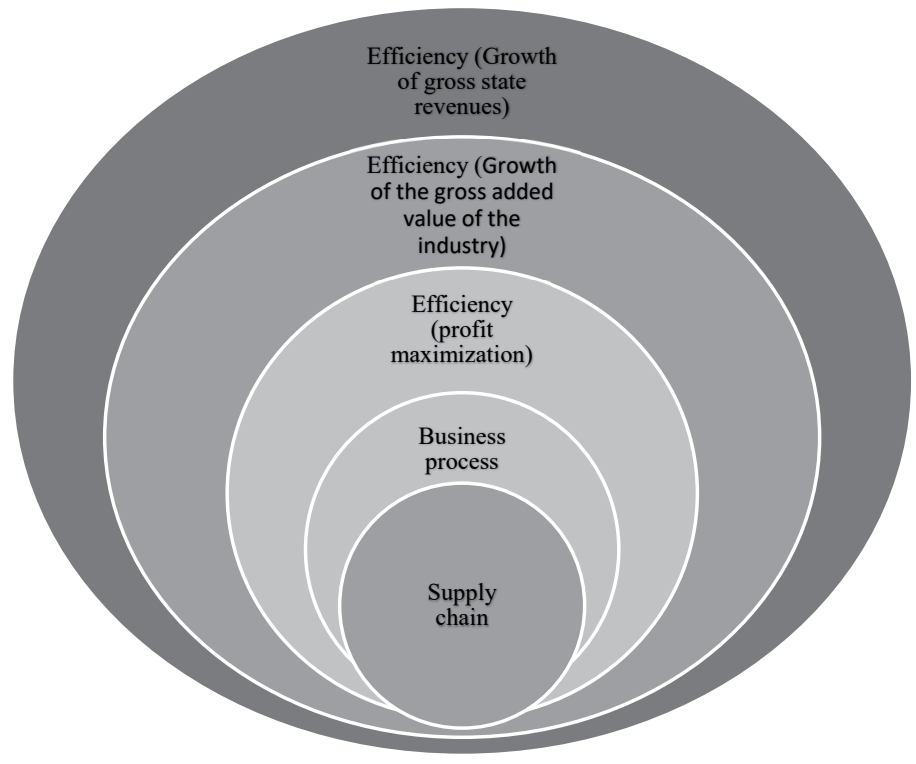

Fig. 1. The "enlargement" of the scale of the supply chains concept from micro to macroeconomic essence

There are a large number of definitions of the term "supply chain management", but the interpretation of this term given in 1998 by the Logistics Management Council is generally accepted in the USA and Europe: "Supply chain management is the integration of key business processes (mainly logistics), starting from the end consumer and involving all intermediaries and suppliers of goods, services and information that add value to consumers and other interested parties" (SCOR-m, 2010). In order to determine the main goals and development strategies of both global and domestic companies, as well as external and internal factors that have a direct impact on the development of companies, the trends in world trade in the time period from 2010 to 2024 will be analyzed, taking into account the forecast component by export and import, classifying the division of research subjects into four groups: Emerging and developing Asia, Emerging and developing Europe, Middle East and Central Asia, Sub-Saharan Africa. Considering the supply chain in trade as a business process, the size of the business on a global scale is illustrated (Fig. 2), using the statistics of the International Monetary Fund (IMF, 2019). According to Fig. 2, we draw conclusions about the predicted, at least stable, trend of maintaining export and import volumes in the world trade for the next four years. Despite the development of logistics and supply chain management worldwide, many theoretical as well as practical problems with the reliability of supply chains, as business processes, remain unresolved. These include, in our opinion, the problem of developing a classification of methods and models of assessing and ensuring the reliability of operations while minimizing logistical risks in supply chains. The evaluation of the efficiency of the supply chain and, in particular, its reliability is made by comparing the performance of the company with the performance of the leading companies in this field of business. Obviously, such a comparison does not always allow to evaluate correctly both the efficiency and the reliability of the supply chain. For example, if the proportion of error-free or "perfectly" executed orders in the best companies is $99 \%$, and in this company - $98 \%$, then this does not mean that the security of supply in this company is lower than in the best companies. Different companies may differ in both product parameters and customer requirements for product deliveries of the same purpose. These options and 
requirements may differ for units within the same company, but operate in different markets or in different regions. Consequently, direct comparisons of companies by such indicators as the proportion of error-free ("perfect") orders or lead times are not always possible. Effective management is seen as the most important opportunity to gain competitive advantage. This explains the increased interest in the system of indicators of management system evaluation in business processes, in the supply chains. After all, with the help of a properly constructed management-analytical system of indicators it is possible to calculate certain values, to identify a tendency and, most importantly, to plan the whole process in the supply chains based on specific figures and results. To manage reliability, security and sustainability of the business processes as supply chains, unify the system of characteristics of the apparatus of "reliability management", managing the total risk of logistics, which can serve "benchmarking" (Kuksa I., 2019) in achieving the planned efficiency of any economic activity (Fig. 3).

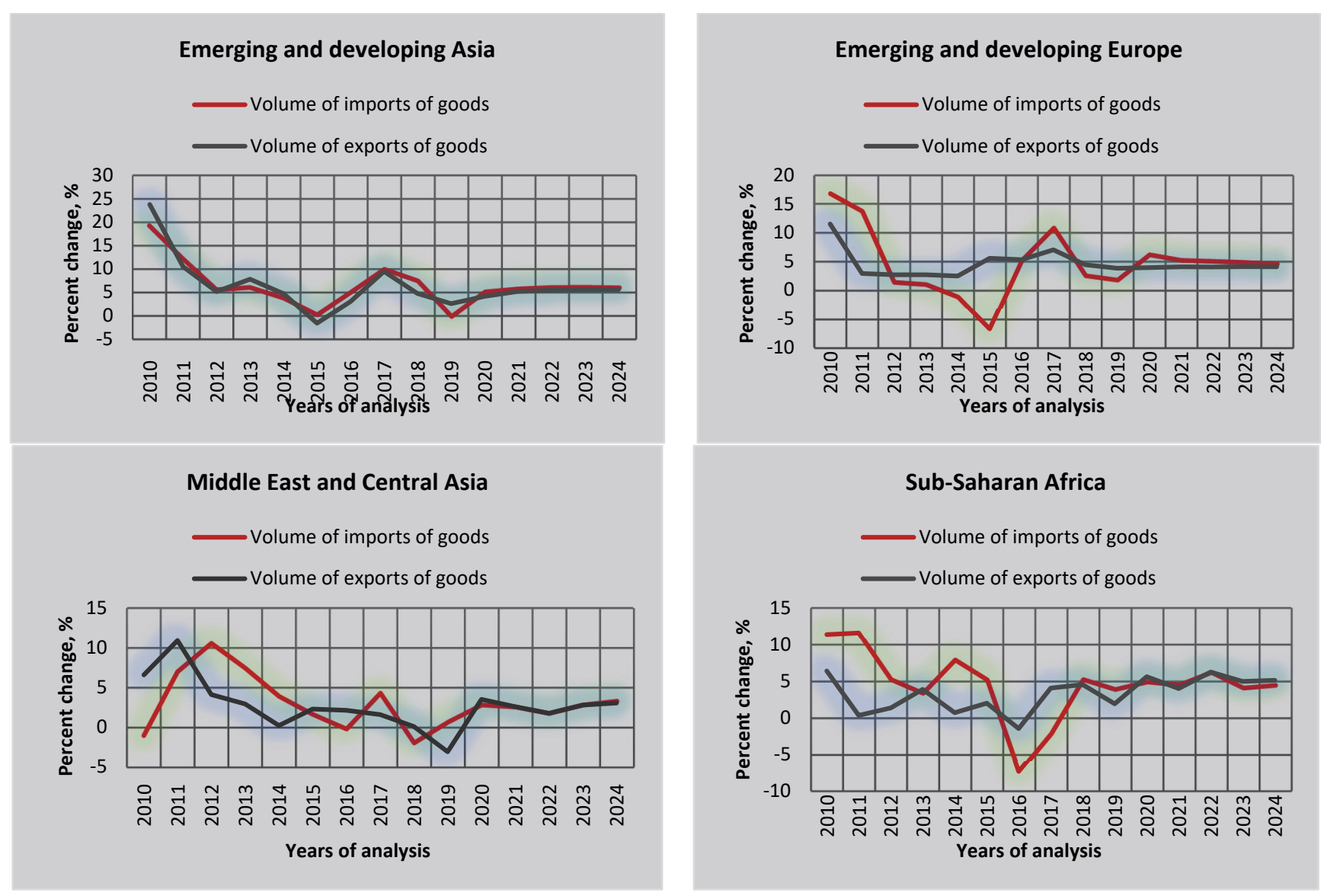

Fig. 2. Tendency of export and import of goods with forecast component (differentiation groups). International Monetary Fund, World Economic Outlook Database, October 2019.

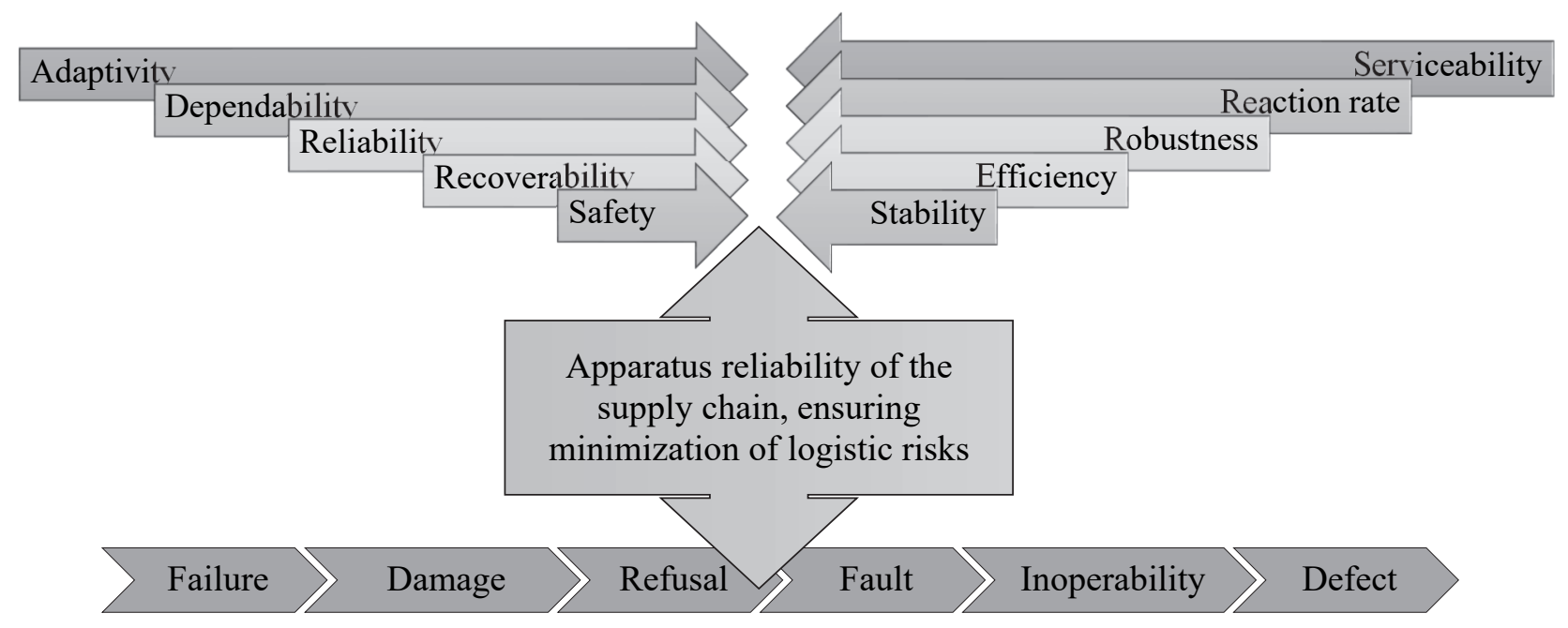

Fig. 3. Logistic representation of the apparatus of the business process "management reliability" 


\section{Research methods}

An analysis of the use of mathematical models and methods for assessing and improving the reliability of business processes as supply chains, in our opinion, should begin by examining the main properties of the global economy, identifying a range of key indicators, indicating trade activity as a descriptor, thereby finding indicators to ensure their reliability in globalization space. The economic approach to improving the reliability of business processes, both in the unimodal and global aspects, is based on methods and mathematical models for planning logistics operations in the face of uncertainty.

\section{Research results and discussion}

The study "Globalize or customize: financing the right balance" emphasizes the importance of risk management in the supply chains of companies and notes that "the restructuring of the supply chain, aimed at increasing its efficiency, while maintaining its flexibility and ability to respond to constantly changing conditions, will be decisive value while increasing competitiveness. Reliability of supply and product quality is a basic expectation. Fulfillment of orders of small volume, with high added value and high variability of product characteristics should be supported by appropriate tools for aggregating and forecasting both demand and production capacities. All this must be provided technologically through real-time collaboration and through a platform for exchanging information at all levels of the supply chain" (Ey, 2017). In addition, one of the priority areas for the development of companies is adaptation to new business models aimed at reducing vulnerability to risks, ensuring sustainability and increasing profitability. A decisive factor for success against the background of many external risks should be a system of forecasting trends and quick analysis of scenarios.

\section{Table 1}

Dataset: Global Revenue Statistics Databasefor the modeling (2011-2017 Year)

\begin{tabular}{|c|c|c|c|c|}
\hline \multicolumn{3}{|c|}{ Dataset: countries of the Pacific region } & $\begin{array}{c}\text { Australia } \\
\text { (conv.) }\end{array}$ & $\begin{array}{c}\text { New } \\
\text { Zealand } \\
\text { (conv.) }\end{array}$ \\
\hline Level of government & $\begin{array}{l}\text { formance indicator } \\
\text { Tax revenue }\end{array}$ & Indicator & \multirow[b]{2}{*}{$\mathrm{Ya}_{\mathrm{a}}$} & \multirow[b]{2}{*}{$\mathrm{Y}_{\mathrm{n}}$} \\
\hline Total & Total tax revenue & $\begin{array}{l}\text { Total tax } \\
\text { revenue in USD }\end{array}$ & & \\
\hline \multicolumn{5}{|c|}{ Influencing indicator } \\
\hline $\begin{array}{l}\text { Classification criteria } \\
\text { Main activity (Business enterprise R\&D expenditure by } \\
\text { industry: Wholesale and retail trade; repair of motor vehicles } \\
\text { and motorcycles }(G) \text { ) }\end{array}$ & PPP Dollars - Current prices & $\begin{array}{l}\text { Unit } \\
\text { US Dollar, } \\
\text { Millions }\end{array}$ & $X_{\mathrm{a} 1}$ & $X_{n 1}$ \\
\hline $\begin{array}{l}\text { Subject } \\
\text { CPI: 01-12 - All items (Consumer price indices (CPIs)) }\end{array}$ & $\begin{array}{l}\text { Measure } \\
\text { Percentage change on the same } \\
\text { period of the previous year }\end{array}$ & Frequency & $\mathrm{X}_{\mathrm{a} 2}$ & $\mathrm{X}_{\mathrm{n} 2}$ \\
\hline Classification of Products by Acitvity ver 2.1 & Index type & Imports & $\mathrm{X}_{\mathrm{a} 3}$ & $X_{n} 3$ \\
\hline Merchandise Trade Price Index Database by CPA & Laspeyres index & Exports & $\mathrm{X}_{\mathrm{a} 4}$ & $X_{n} 4$ \\
\hline $\begin{array}{l}\text { Level of government } \\
\text { Total }\end{array}$ & $\begin{array}{l}\text { Tax revenue } \\
\text { Taxes on goods and services }\end{array}$ & $\begin{array}{l}\text { Indicator } \\
\text { Total tax } \\
\text { revenue in USD }\end{array}$ & $\mathrm{X}_{\mathrm{a} 5}$ & $\mathrm{X}_{\mathrm{n} 5}$ \\
\hline $\begin{array}{l}\text { Subject } \\
\text { Industry contribution to business sector labour productivity } \\
\text { (Productivity and ULC by main economic activity (ISIC } \\
\text { Rev.4)) }\end{array}$ & $\begin{array}{l}\text { Measure } \\
\text { Annual industry contribution, } \\
\text { percentage points }\end{array}$ & Percentage & $\mathrm{X}_{\mathrm{a} 6}$ & $\mathrm{X}_{\mathrm{n} 6}$ \\
\hline Measure & Activity & Unit & & \\
\hline $\begin{array}{l}\text { Gross value added per person employed, constant prices } \\
\text { (Annual growth/change) } \\
\text { Measure }\end{array}$ & $\begin{array}{l}\text { G_I: Wholesale retail trade } \\
\text { accommodation food services, } \\
\text { transportation and storage } \\
\text { Activity }\end{array}$ & $\begin{array}{l}\text { Percentage } \\
\text { Unit }\end{array}$ & $\mathrm{X}_{\mathrm{a} 7}$ & $\mathrm{X}_{\mathrm{n} 7}$ \\
\hline $\begin{array}{l}\text { Total employment (number of persons employed) (Annual } \\
\text { growth/change) }\end{array}$ & $\begin{array}{l}\text { G_I: Wholesale retail trade } \\
\text { accommodation food services, } \\
\text { transportation and storage }\end{array}$ & Percentage & $X_{a} 8$ & $\mathrm{X}_{\mathrm{n} 8}$ \\
\hline Measure & Activity & Unit & & \\
\hline $\begin{array}{l}\text { Labour compensation per hour worked (Annual } \\
\text { growth/change) }\end{array}$ & $\begin{array}{l}\text { G_I: Wholesale retail trade } \\
\text { accommodation food services, } \\
\text { transportation and storage }\end{array}$ & Percentage & $\mathrm{X}_{\mathrm{a} 9}$ & $\mathrm{X}_{\mathrm{n} 9}$ \\
\hline
\end{tabular}


To determine the measure of the influence of factors on supply chain management, the following factors from the perspective of interpreting supply chain management will be chosen: managing a business process, the key purpose of which is to maximize the efficiency of economic activity, minimizing logistics risks due to the identification and management of vulnerability indicators. Based on the availability of statistical information, the aim is to build a consolidated two-tier model of finding resources to ensure economic efficiency, as well as to ensure the reliability of business processes in world trade. For modeling purposes, Pacific, Australia, and New Zealand profiles were selected as subjects of the study. The high level of development of the leading Pacific countries is the main reason for the increasing role of this economic union in the world economy. This region occupies a leading position in international trade relations. It accounts for $40 \%$ of the volume of world trade and foreign economic operations. Such a significant share of participation in international trade operations supports the intensity of industrial production and accounts for $60 \%$ of the global industry (OECD, 2020). To create a set of features that characterize the main trends of world trade in the array of macroeconomic categories, 9 influential indicators of a particular type of economic activity and a resultant indicator of total tax revenues, which provide a conceptual framework that determines government revenues for the period 2011-2017, were selected. In order to optimize the perception of the results of the analytical study, they were conditionally designated and presented in Table 1 as an information array. The following hypotheses is proposed regarding the impact of the influential indicators outlined on the performance indicator:

1. Increase in Research and Development spending in the sector of the entrepreneurial activity in the industry (Wholesale and retail trade; repair of motor vehicles and motorcycles) $(\mathrm{G})\left(\mathrm{X}_{1}\right)$ contributes to an increase in overall tax revenue in the country (Y), economic growth;

2. Reducing consumer prices (inflation index) $\left(\mathrm{X}_{2}\right)$ contributes to an increase in overall tax revenue in the country $(\mathrm{Y})$, economic growth;

3. Changes in trade prices for goods (imports) $\left(\mathrm{X}_{3}\right)$ contribute to an increase in overall tax revenues in the country $(\mathrm{Y})$, economic growth;

4. Changing trade prices for goods (exports) $\left(\mathrm{X}_{4}\right)$ contributes to an increase in overall tax revenue in the country $(\mathrm{Y})$, economic growth;

5. The increase in tax revenues from trade in goods and services $\left(\mathrm{X}_{5}\right)$ contributes to the increase in total tax revenues in the country (Y), economic growth;

6. Increase in productivity in the industry (Wholesale and retail trade; repair of motor vehicles and motorcycles $(G))\left(\mathrm{X}_{6}\right)$, contributes to an increase in total tax revenue in the country (Y), economic growth;

7. Increase in gross added value per employee in the industry (Wholesale and retail trade; repair of motor vehicles and motorcycles $(\mathrm{G}))\left(\mathrm{X}_{7}\right)$, contributes to the increase in total tax revenues in the country $(\mathrm{Y})$, economic growth;

8. Increase in total employment in the industry (Wholesale and retail trade; repair of motor vehicles and motorcycles $(\mathrm{G}))\left(\mathrm{X}_{8}\right)$, contributes to an increase in total tax revenues in the country (Y), economic growth;

9. An increase in hourly wages in the industry (Wholesale and retail trade; repair of motor vehicles and motorcycles $(\mathrm{G}))\left(\mathrm{X}_{9}\right)$ contributes to an increase in overall tax revenue in the country $(\mathrm{Y})$, economic growth.

Linear regression functions have an impact on the formation of total tax revenue for all nine factors. The data of the study are accumulated in Table 2.

\section{Table. 2}

Initial visualization of the results of resolving hypothetical claims about the existing relationship between performance and impact indicators

\begin{tabular}{|c|c|c|c|c|c|c|}
\hline \multirow[b]{2}{*}{$\begin{array}{l}\text { Indicator (X) Link } \\
\text { Hypothesis } \\
\text { on indicator (B) }\end{array}$} & \multicolumn{3}{|c|}{ Australia } & \multicolumn{3}{|c|}{ New Zealand } \\
\hline & $\begin{array}{l}\text { Relationship } \\
\text { between the studied } \\
\text { indicators } \\
\text { (Coefficient of } \\
\text { determination) }\end{array}$ & $\begin{array}{l}\text { Indicator Weight } \\
(\mathrm{X}) \text { to }(\mathrm{Y}) \\
\text { (Regression } \\
\text { Ratio) }\end{array}$ & $\begin{array}{l}\text { Conclusion on the } \\
\text { hypothesis confirmation }\end{array}$ & $\begin{array}{l}\text { Relationship between } \\
\text { the studied indicators } \\
\text { (Coefficient of } \\
\text { determination) }\end{array}$ & $\begin{array}{l}\text { Indicator Weight }(\mathrm{X}) \text { to } \\
\text { (Y) (Regression Ratio) }\end{array}$ & $\begin{array}{l}\text { Conclusion on the } \\
\text { hypothesis confirmation }\end{array}$ \\
\hline 1 & 0,319 & $-0,149$ & Minor impact & 0,00005 & $-0,0008$ & Disproved \\
\hline 2 & 0,238 & 20,371 & Minor impact & 0,197 & $-1,778$ & Minor impact \\
\hline 3 & 0,066 & 1,099 & Disproved & 0,321 & $-0,677$ & Minor impact \\
\hline 4 & 0,022 & 0,307 & Disproved & 0,044 & 0,105 & Disproved \\
\hline 5 & 0,604 & 2,064 & Confirmed & 0,977 & 2,889 & Confirmed \\
\hline 6 & 0,114 & $-2,473$ & Minor impact & 0,001 & $-0,167$ & Disproved \\
\hline 7 & 0,028 & $-1,743$ & Disproved & 0,050 & $-0,486$ & Disproved \\
\hline 8 & 0,0004 & 0,232 & Disproved & 0,770 & $-0,917$ & Confirmed \\
\hline 9 & 0,025 & $-1,012$ & Disproved & 0,194 & $-0,300$ & Minor impact \\
\hline
\end{tabular}

Interpretation of the results of this study makes it possible to draw the following conclusions on determining the resources to ensure the formation of general tax revenues in the countries studied. Visualizations in the form of linear equations and trend lines are presented in Fig. 4. In both countries, increasing tax revenues from trade in goods and services contributes to an increase in overall tax revenues in the country, with a fixed position of other factors of the model, will cause a real increase in the 
country's financial resources. Separately in New Zealand Growth in total employment in the industry (Wholesale and retail trade; repair of motor vehicles and motorcycles $(\mathrm{G})$ ) contributes to an increase in overall tax revenue in the country, economic growth.

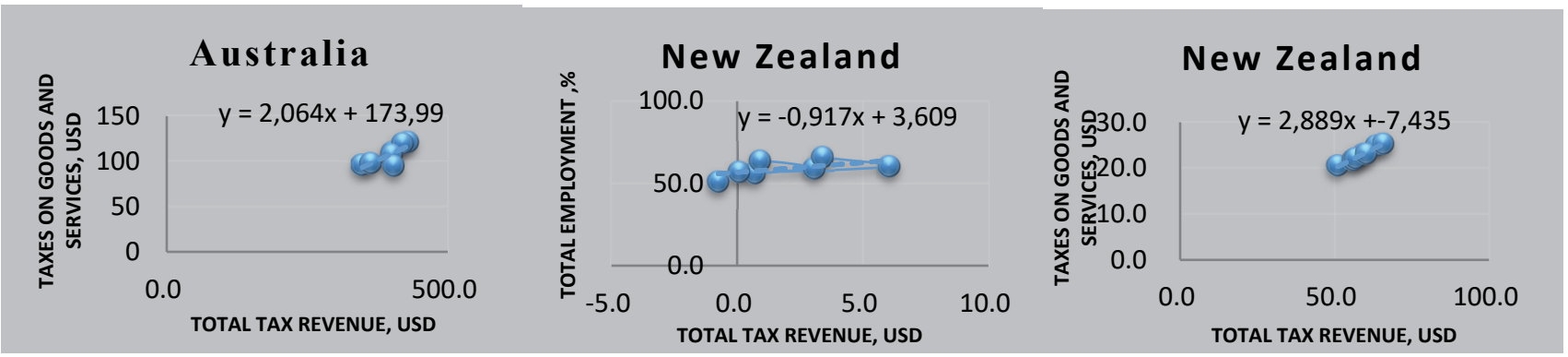

Fig. 4. Visualization of confirmed hypotheses in the form of linear equations

The next step is to build a two-tier model of business process reliability management, taking into account the results of linear regression models based on the profiles of Australia and New Zealand, as well as the globalization aspect of the projected global trade trend. Model decoupling is presented in Figure 5.

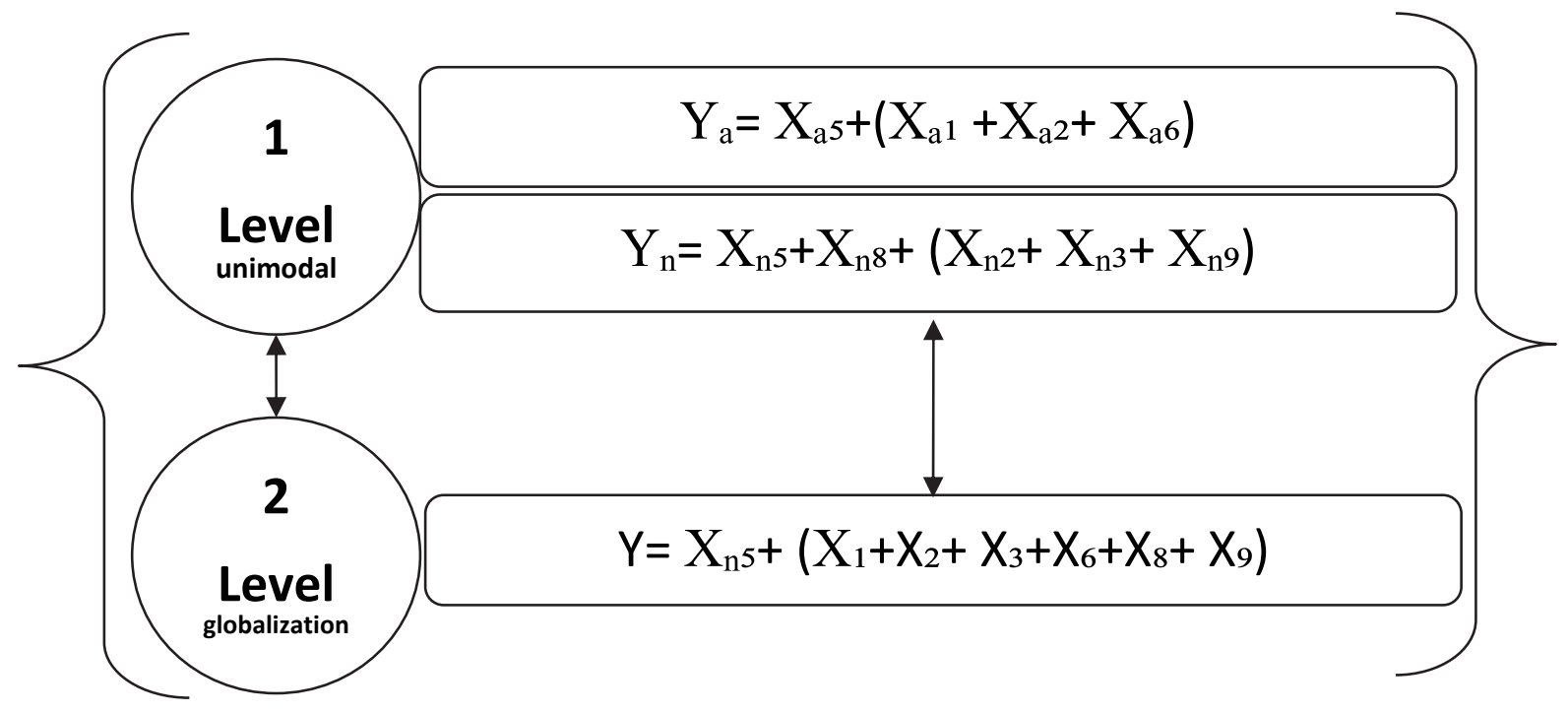

Fig. 5. Two-tier model of "reliability management" of business processes

The proposed approach allows to quantify the impact of individual factors on macroeconomic performance indicators of the economy in compliance with mathematical logic and the construction of the necessary analytical linear models at the request of each stage of the study. It is worth noting that at the first level of the model, unimodal recommendations are considered for finding tax revenue reserves for each individual economy of the country under study. At the second level, globally coinciding influencing indicators are determined. The control unit and foundation of this model should be the "reliability management" apparatus, ordered in Figure 3, that is, the model is promising from the point of view of further scientific developments and can be easily adapted to a particular economic situation.

\section{Conclusion}

1. An interpretation of the logistic representation of the system of characteristics of the "reliability management" apparatus that manages the total logistics risk is proposed, which serves as a conceptual foundation for the procedure of creating new models of assessment and ensuring the reliability of business processes.

2. The analysis of world trade trends in the time interval from 2010 to 2024, taking into account the forecast component in terms of exports and imports, classifying the research subjects into four groups: Emerging and developing Asia, Emerging and developing Europe, Middle East and Central Asia, Sub -Saharan Africa, allowed to construct a probable trend, at least stable, of the tendency of maintaining the volume of export and import in world trade.

3. The complex two-tier model for analytical estimation of key indicators of search of economy efficiency reserves is developed; a methodological approach is proposed, which allows to trace the relationship of the model of general world tendencies with 
key indicators of efficiency of economy of an individual state, based on the apparatus of characteristics of business processes "reliability management", with particular emphasis on vulnerability indicators.

\section{References}

Allen, D. W., Berg, C., Davidson, S., Novak, M., \& Potts, J. (2019). International policy coordination for blockchain supply chains. Asia \& the Pacific Policy Studies, 6(3), 367-380.

Allen, D. W., Berg, A., \& Markey-Towler, B. (2018). Blockchain and supply chains: V-form organisations, value redistributions, de-commoditisation and quality proxies. Allen, DWE, Berg A and Markey-Towler, B (2019) 'Blockchain and Supply Chains: V-form Organisations, Value Redistributions, De-commoditisation and Quality Proxies', The Journal of the British Blockchain Association, 2(1), 57-65.

Bochkarev, A. A., \& Zaitsev, E. I. (2010). Optimization of supply planning in multi-level network structures taking into account reliability. Logistics and Supply Chain Management, 2(37), 38-48.

Casey, M. J., \& Wong, P. (2017). Global supply chains are about to get better, thanks to blockchain. Harvard Business Review. Retrieved from https://hbr.org/2017/03/global-supply-chains-are-about-to-get-better-thanks-to-blockchain

Globalize or customize: finding the right balance: https://www.ey.com/Publication/vwLUAssets/EY-global-steel-20152016/\$FILE/EY-global-steel-2015-2016.pdf

International Monetary Fund (IMF): https://www.imf.org/external/pubs/ft/weo/2019/02/weodata/

Mor, R., Singh, S., Bhardwaj, A., \& Singh, L. (2015). Technological Implications of Supply Chain Practices in Agri-Food Sector: A Review. International Journal of Supply and Operations Management, 2(2), 720-747.

Organisation for Economic Co-operation and Development (OECD: https://stats.oecd.org/Index.aspx

Sabegh, M., Ozturkoglu, Y., \& Kim, T. (2016). Green supply chain management practices' effect on the performance of Turkish business relationships. International Journal of Supply and Operations Management, 2(4), 982-1002.

Saha, S., Chakrabarti, T. (2018). Two-echelon supply chain model for deteriorating items in an imperfect production system with advertisement and stock dependent demand under trade credit. International Journal of Supply and Operations Management, 5(3), 207-217.

Supply Chain Operations Reference-model. Version 10.0. The Supply Chain Council, Inc., August 2010. - 856 p.: http://cloud.ld.ttu.ee/idu0010/Portals/0/Harjutustunnid/SCOR10.pdf.

Tiwari, S., Jaggi, C. K., Gupta, M., \& Cárdenas-Barrón, L. E. (2018). Optimal pricing and lot-sizing policy for supply chain system with deteriorating items under limited storage capacity. International Journal of Production Economics, 200, 278290.

Vasyurenko, L., \& Kuksa, I. (2018). Financial provisions for individualization of the level of loan payment. Financial and Credit Activity: Problems of Theory and Practice, 3(26), 469-476. http://dx.doi.org/10.18371/fcaptp.v3i26.144258

Vasyurenko, L., Kuksa, I., \& Danylenko, V. (2019). Ordering Logistics Management of Professional Standard Attribution of the Higher Education Specialist. International Journal of Supply and Operations Management, 6(4), 389-394. 
(C) 2020 by the authors; licensee Growing Science, Canada. This is an open access article distributed under the terms and conditions of the Creative Commons Attribution (CC-BY) license (http://creativecommons.org/licenses/by/4.0/). 